\title{
Forced Migration and Reproductive Rights: Pregnant Women Fleeing Venezuela
}

Received: May 31, 2020

Approved: March 4, 2021

Doi: https://doi.org/10.12804/revistas.urosario.edu.co/acdi/a.9188

\section{Cindy Hawkins Rada*}

Abstract: Numerous pregnant Venezuelan women have fled Venezuela. To some of them, the health system crisis has increased risk to their lives and their children. Thousands of women have arrived in Colombia in search of reproductive health care. Notwithstanding Colombia's government efforts to provide some relief measures to the massive influx of Venezuelan migrants, pregnant women are not receiving the prenatal and postnatal care they need. One of the primary barriers to health care access is their immigration status and the health system structure regarding migrants. Considering the major debates related to migrants' and refugees' access to health care — such as public health issues and the "magnet," "free rider," and health care costs concerns - this paper studies Colombia's international human rights obligations concerning their immigration status and the right to reproductive health. The research

* Abogada de la Universidad del Norte, Especialista en Derecho de los Negocios de la Universidad Externado de Colombia y LL.M. Transnational, International, and Comparative Law de University of Georgia. Becaría Fulbright para Líderes Afrodescendientes, cohorte 2019. Email: chawkinsrada@gmail.com orcID: http://orcid. org/0000-0003-3500-6827

How to cite this article: Hawkins Rada, Cindy. Forced Migration and Reproductive Rights: Pregnant Women Fleeing Venezuela. Anuario Colombiano de Derecho Internacional (ACDI) 15, (2022), 223-265. https:// doi.org/10.12804/revistas.urosario.edu.co/acdi/a.9188 
allows concluding that the government measures have been insufficient to meet these obligations.

Keywords: Forced migration; reproductive rights; pregnant Venezuelan women; women refugees; Venezuelan migrants.

Migraciones forzadas y derechos reproductivos: mujeres embarazadas huyendo de Venezuela

Resumen: numerosas mujeres venezolanas embarazadas han huido de Venezuela. Para algunas de ellas, la crisis de salud ha incrementado el riesgo para sus vidas y sus hijos/as. Miles han llegado a Colombia en busca de atención médica. A pesar de los esfuerzos del gobierno para adoptar medidas de alivio a la afluencia masiva de migrantes, las mujeres embarazadas no reciben atención prenatal ni posnatal. Una de las principales barreras es su estatus migratorio y la estructura del sistema de salud. Teniendo en cuenta los principales debates en relación con el acceso a la salud de personas migrantes y refugiadas, como los problemas de salud pública, la preocupaciones del "imán", del "polizón” y sobre los costos en la atención médica, este artículo estudia las obligaciones internacionales de derechos humanos de Colombia con respecto a su estatus migratorio y el derecho a la salud reproductiva. La investigación permite concluir que las medidas gubernamentales han sido insuficientes para cumplir con estas obligaciones.

Palabras clave: migración forzada; derechos reproductivos; mujeres embarazadas venezolanas; mujeres refugiadas; migrantes venezolanas.

Migração forçada e direitos reprodutivos: mulheres grávidas fugindo da Venezuela

Resumo: inúmeras mulheres grávidas venezuelanas fugiram da Venezuela. Para algumas delas, a crise na saúde aumentou o risco para suas vidas e de seus filhos. Milhares vieram para a Colômbia em busca de cuidados de saúde. Apesar dos esforços do governo para adotar medidas para aliviar a imigração massiva, as mulheres grávidas não recebem cuidados prénatal e pós-natal. Uma das principais barreiras é seu status de imigrante 
e a estrutura do sistema de saúde. Tendo em conta os principais debates em relação ao acesso à saúde para imigrantes e refugiados, como os problemas de saúde pública, a preocupação do "imã”, a preocupação do "clandestino / free rider" e as preocupações com os custos da atenção médica, este artigo estuda as obrigações internacionais de direitos humanos da Colômbia em relação à sua situação migratória e o direito à saúde reprodutiva, para concluir que as medidas governamentais têm sido insuficientes para o cumprimento de tais obrigações.

Palavras-chave: migração forçada; direitos reprodutivos; mulheres grávidas venezuelanas; mulheres refugiadas; imigrantes venezuelanas.

\section{Introduction}

Venezuela is facing an enormous health system crisis with shortages in medicines, supplies, and utilities. ${ }^{1}$ This crisis has caused a differentiated impact on women, especially pregnant women, considering the lack of reproductive health care and the increase in maternal and child mortality. Given these circumstances, thousands of pregnant women have fled to Colombia in search of reproductive health care. ${ }^{2}$ Many international organizations and $\mathrm{NGOs}^{3}$ have documented the need for reproductive health

1 Human Right Watch [HRW] and Johns Hopkins Bloomberg School of Public Health [JHSPH], Venezuela's Humanitarian Emergency. Larga-Scale UN Response Needed to Address Health and Food Crises (HRW and JHSPH, 2019), https://www.hrw.org/sites/default/files/ report_pdf/venezuela0419_web.pdf

2 Luisa Henao et al., "Calidad de vida percibida por las madres gestantes venezolanas, en la ciudad de Medellín, durante el periodo de 2018-2019", Revista Cies 11, (2020): 50-66, http://www.escolme.edu.co/revista/index.php/cies/article/view/280

3 United Nations, Save the Children, Amnesty International, UNHCR, among others, have reported many cases of women seeking health care in Colombia due to their pregnancies. To access more information, see: United Nations Colombia, Mujeres embarazadas huyen de la falta de atención médica en Venezuela, https://nacionesunidas.org.co/noticias/mujeres-embarazadas-huyen-de-la-falta-de-atencionmedica-en-venezuela/; Médicos sin Fronteras, Brindamos atención a migrantes venezolanos en Colombia, https://www.msf.es/actualidad/colombia/brindamos-atencionmigrantes-venezolanos-colombia; Alejandra Romo, "Mujeres embarazadas huyen de la falta de atención médica en Venezuela", United Nation's High Commissioner for Refugees, July 23, 2019, https://www.acnur.org/noticias/historia/2019/7/5d374bcb4/ 
care as the principal motivation to migrate to Colombia. Nevertheless, most pregnant women arrive in Colombia with irregular immigration status, and the government provides only emergency health care.

This paper addresses, in turn, the refugee status of Venezuelan pregnant women under the Cartagena Declaration, Colombia's human rights obligations to provide reproductive health care under the interAmerican system of human rights, and the need for domestic measures to guarantee their human rights. The first part of the article describes how the lack of reproductive health care in Venezuela forces pregnant women to flee to Colombia, as well as the situation they are facing upon their arrival. Part two looks at the inter-American legal framework regarding refugees, particularly refugees' right to health. Next, the article presents the considerations of Colombia's treatment of Venezuelan pregnant women and further contemplates the need for domestic measures regarding reproductive health care. Finally, the author points out the need and importance for the recognition of pregnant women as refugees and their right to reproductive health.

\section{The Lack of Reproductive Health Care in Venezuela Forces Pregnant Women to Flee to Colombia}

Venezuela is facing a socio-economic and political crisis that has affected daily life activities, such as access to health care. This section argues that numerous pregnant women have been forced to flee to Colombia due to the magnitude of the crisis affecting Venezuela's health care system in comparison to the health care context of the region, particularly Colombia's. First, it presents the description and evaluation of Venezuela's health care system's current situation. Second, it shows the analysis of the differentiated impact that the situation has on pregnant women. Finally, it depicts the study of the context upon their arrival in Colombia.

mujeres-embarazadas-huyen-de-la-falta-de-atencion-medica-en-venezuela.html; Pilar Sanmartin, "Huir para ver la luz: el éxodo de las embarazadas venezolnas," Amnesty International, May 6, 2018, https://www.amnesty.org/es/latest/news/2018/05/huir-paraver-la-luz-el-exodo-de-las-embarazadas-venezolanas/ 


\subsection{Venezuelan Health Care System Crisis}

Two years after the beginning of the economic crisis, ${ }^{4}$ Venezuela's health care system entered into stress due to funding, human resources, and supply issues. Consequently, the health system showed evidence of significant deterioration leading to a crisis "in all its components." ${ }^{5}$ There is a decay of infrastructure, a decline of health professionals (emigration), a shortage of supplies, vaccines, and medicines, and an opacity of health information, among other elements contributing to insufficient coverage and effective access to public health services in the entire country. ${ }^{6}$

The Venezuelan health crisis started to escalate in 2012. Researchers consider that the situation is more dismal than they expected. ${ }^{7}$ Unlike most Latin American countries where health care is improving progressively in coverage, services, and estimations, ${ }^{8}$ Venezuela's system shows an alarming deterioration without data indicators since $2017^{9}$ and suggestions of aggravation. ${ }^{10}$

4 Venezuela is facing a severer economic crisis than any Latin American country in modern history. Specifically, some of the circumstances that reflect on the Venezuelan crisis are, for example, that forty percent of its GDP has fallen, its Central Bank ran out of operative international reserves, and seventy-six percent of imports has been cut, a dire fiscal situation, among others. Leonardo Vera, “¿Cómo explicar la catástrofe económica venezolana?", Revista Nueva Sociadad 274, (2018): 83-96.

5 Alejandra Carrillo, "Sistema de salud en Venezuela", Cadernos de Saúde Pública 34, No. 3 (2018): 12, https://doi.org/10.1590/0102-311X00058517

6 Ibid.

7 Melody Schreiber, "Researchers Are Surprised by the Magnitud of Venezuela's Health Crisis," npr.org, April 5, 2019, https://www.npr.org/sections/goatsandsoda/2019/04/05/709969632/researchers-are-surprised-by-the-magnitude-of-venezuelas-health-crisis

8 Pan American Health Organization [PAHO], Salud en Sudamérica. Edición 2012. Panorama de la situación de saludy de las politicas y sistemas de salud (Washingto D. C.: PAHO and wHO, 2012), https://www.paho.org/chi/images/PDFs/salud $\% 20$ en $\% 20$ sam $\% 20$ 2012\%20(ene.13).pdf; PAHO, Once países de América Latina y el Caribe registraron avances en la reducción de la mortalidad maternal según nuevo informe de la ONU, May 6, 2014, https://www. paho.org/en/news/6-5-2014-11-countries-latin-america-and-caribbean-have-reducedmaternal-mortality-new-data

9 HRw, Venezuela: Numbers Highlight Health Crisis, November 15, 2018, https://www. hrw.org/news/2018/11/15/venezuela-numbers-highlight-health-crisis

10 PAHO and JHSPH, Venezuela' Humanitarian Emergency...; PAHO and WHO, PAHO's Response to Maintaining an Effective Techinical Cooperation Agenda in Venezuela and 
Notably, there has been a deterioration in emergency services, in regular access to utilities by hospitals, and in the capacity to respond to disease outbreaks. A high percentage of hospitals have reported these shortages. In 2018, eighty-eight percent of hospitals reported medication shortages. There was seventy-nine percent of shortages in surgical supplies, and thirty-three percent of hospital beds were not available for patients. Also, hospitals faced shortages in essential utility services, reporting a sixty-seven percent shortage in electricity and a seventy percent shortage in water in $2018 .{ }^{11}$

Hospitals have requested patients to bring their medical supplies, including syringes and scalpels. They have also requested food, soap, and water. Additionally, the lack of medications and the impossibility to buy them due to inflation have forced people to buy medicines from the black market, despite their lack of quality guarantee. Other patients cannot even afford those, either. ${ }^{12}$

Although there are significant barriers to health care access in Latin American countries, various factors differentiate them from the severe shortage situation in Venezuela. For example, in Colombia, there has been an increase in health care coverage. Around ninety percent of the population is insured, but only seventy-five percent of them access health care. There are various reasons not to access health care. The 54.9 percent of cases do not access because of the idea that the case was mild. The 11.5 percent because of the lack of economic means. Nevertheless, care quality, bureaucracy, distance, lack of time, and denial, among others, are factors that do not affect to a greater extent the health care access in Colombia. ${ }^{13}$

Moreover, in Venezuela, 22000 physicians left the country between 2014 and 2018, which represents thirty-three percent of the country's

Neighboring Member States, https://www3.paho.org/hq/index.php?option=com docman\&view $=$ download $\&$ category_slug $=162$-en-9841\&alias $=45491-$ ce 162 -inf-22e-paho-tc-respond-491\&Itemid=270\&lang=en

11 PAHO and JHSPH, Venezuela' Humanitarian Emergency..., 15.

12 Ibid., 16.

13 Jhorland Ayala, "La salud en Colombia: más cobertura pero menos acceso", Documentos de Trabajo sobre Economía Regional, No. 24 (2014), https://www.banrep.gov.co/ sites/default/files/publicaciones/archivos/dtser_204.pdf 
physicians reported in $2014,{ }^{14}$ and the number has increased since the crisis deepened. The migration of health care workers has affected some specialty areas, such as laboratory testing: 6000 bio-analysts and laboratory technicians have migrated, and between 3000 and 5000 nurses have left the country. ${ }^{15}$ According to the Pan American Health Organization (PAHO), the decrease of physicians in Venezuela is against the increase in most of the South American countries. ${ }^{16}$

Despite this information, the crisis has been challenging to track, and it could be even worse. The Venezuelan government denies it; what is worse, it stopped publishing health statistics in $2017 .{ }^{17}$ Therefore, the official situation is undocumented. The numbers provided in this paper represent data gathered through the efforts of experts and non-governmental organizations. Even though the situation is underdocumented, adverse impacts in the reproductive health care of Venezuelan women have been identified.

\subsection{Reproductive Health Care of Pregnant Women in Venezuela}

The Venezuelan health crisis has hindered access to quality reproductive health care in general. However, it has also threatened pregnant women, given the increase in maternal and child mortality rates. According to the government's last-available report, child deaths had increased by 30.1 percent and maternal mortality by 65.4 percent between 2015 and $2016 .{ }^{18}$ Venezuela is one of the four Latin American countries ${ }^{19}$

14 In 2014, the Venezuelan Medical Federation reported 66,138 physicians in the country.

PAHO and WHO, PAHO's Response to Maintaining an Effective Techinical Cooperation..., para. 12 .

15 Ibid.

16 PAHO, Salud en Sudamérica. Edición 2012...

17 HRw, Venequla: Numbers Highlight Health Crisis, https://www.hrw.org/ news/2018/11/15/venezuela-numbers-highlight-health-crisis

$18 \mathrm{HRW}$ and JHSPH, Venexuelas Humanitarian Emergency...

19 According to PAHO, Cuba, Guyana, Suriname, and Venezuela were the only Latin American countries where the maternal mortality rate increased since 1990. However, Cuba has a relative low rate in that is lower that 80 deaths per 100,000 live births. 
where the maternal mortality rate has increased since 1990, compared to the decrease in the rest of the region's countries. The World Health Organization (WHO) and the PAHO estimated that 125 pregnant women die per 100000 live births in Venezuela, ${ }^{20}$ while the average in Latin America is 77 maternal deaths per 100000 live births. ${ }^{21}$ In comparison to Colombia, there is not an abysmal gap in rates. Colombia reports 80 deaths per 100000 live births. However, the WHO classified Colombia's rate as "very low," like the majority of the countries in the region, while Venezuela's rate is higher even as a "low" rate.

Moreover, it has been estimated that child mortality has increased forty percent between 2008 and 2016 in Venezuela. ${ }^{22}$ The WHO reported 21.04 infant deaths per 100000 live births, almost double that of Colombia's rate of 11.84 infant deaths per 100000 live births. ${ }^{23}$

Although these estimations show the constant increase in mortality rates in Venezuela reflecting on the deterioration of the health system, it does not seem like a great gap from the situation in countries such as Colombia. However, Venezuela's Government has not published any data since 2017 compared to updates from Colombia. Therefore, researchers estimate the persistent rise of mortality rates. The collapse of the health system, the infectious disease outbreaks, and the declines in nutrition suggest that the situation is dire. ${ }^{24}$

The official data indicated multiple causes for maternal mortality, including hemorrhages, hypertension induced by pregnancy, and illnesses like pneumonia, genitourinary tract infections, and maternal parasites

\footnotetext{
20 WHO, Maternal mortality: Levels and trends 2000 to 2017. Estimates by WHO, Unicef, UNFPA, World Bank Group and the United Nations Population Division. 2019. https://www.who.int/ reproductivehealth/publications/maternal-mortality-2000-2017/en/

21 PAHO, Once países de América Latina y el Caribe registraron avances...

22 PAHO and WHO, PAHO's Response to Maintaining an Effective Techinical Cooperation..., para. 17.

23 IGME-UN Inter-agency Group for Child Mortality Estimation. "Most recent stillbirth, child and adolescent mortality estimates," Accessed January 30, 2021, https:// childmortality.org/

24 Kathleen R. Page et al., "Venezuela's public health crisis: a regional emergency," The Lancet 393, No. 10177 (April 2019): 1254-1260, https://www.thelancet.com/journals/ lancet/article/PIIS0140-6736(19)30344-7/fulltext
} 
that complicate pregnancy, childbirth, and the puerperium. ${ }^{25}$ Also, there has been a significant increase in diseases that cause maternal and infant mortality, such as malaria, diarrhea, measles, and diphtheria. ${ }^{26}$ These increases are also related to the rise in vaccine-preventable diseases and in the levels of malnutrition. ${ }^{27}$

Venezuela's vaccination coverage seems insufficient. For example, out of an overall population of 28515829 people, ${ }^{28} 9399$ were suspected of having measles by 2019, of which 6242 were confirmed, and 76 died. More than 414000 malaria cases were confirmed in 2017. Also, between 2016 and 2019, there were 2512 suspected cases of diphtheria, of which 1559 cases were confirmed, and 270 died. $^{29}$

It is worthwhile to mention that there is a widespread shortage of basic contraception. Unlike Colombia, where the coverage of planned parenthood and contraceptives improved in 2015, the distribution of condoms and birth control in public hospitals in Venezuela has not been available since that same year. Despite barriers to access contraceptives in Colombia, estimations indicate that there is an increase in access even in rural and poor areas. Moreover, the Colombian health system has been considered as effectively addressing the issues of the availability of contraceptives. ${ }^{30} \mathrm{On}$ the contrary, there is an estimation

25 Ministerio del Poder Popular para la Salud, "Resumen de la situación epidemiológica nacional”, Boletín Epidemiológico 61, No. 52 (diciembre 2012), https://www.ovsalud.org/ descargas/publicaciones/documentos-oficiales/Boletin-Epidemiologico-2012.pdf

26 HRW and JHSPH, Venexuelas Humanitarian Emergency..., 2.

27 Kate Hodal, "UN urged to declare full-sclae crisis in Venezuela as health system 'collapses'," The Guardian, April 5, 2019, https://www.theguardian.com/global-development/2019/apr/05/un-urged-to-declare-full-scale-crisis-in-venezuela-as-healthsystem-collapses

28 The overall population in Venezuela has been changing, especially since 2017. However, the United Nations projections estimate that in 2019 the Venezuelan population was 28515829 , presenting a decline of 1.29 percent from 2018. United Nations Department of Economic and Social Affairs. "World population prospects 2019." Population.UN.org, accessed April 27, 2020, https://population.un.org/wpp/Publications/Files/WPP2019_DataBooklet.pdf

29 HRW and JHSPH, Venexuelas Humanitarian Emergency...

30 Jane T. Bertrand, Roberto Santiso-Gálvez and Victoria M. Ward, "Planificación familiar en Colombia: logros de 50 años," Measure Evaluation, https://www.measureevaluation.org/resources/publications/sr-15-118a-es/at_download/document 
of a ninety percent fall of contraceptives inventory in hospitals in Venezuela, which has increased the rates of adolescent pregnancy, sexually transmitted infections, and maternal and infant mortality. According to Venezuela's largest network of family planning clinics, the PLAFAM (for its initials in Spanish), the number of patients suffering complications from clandestine abortions, as well as the number of women seeking permanent sterilization, is increasing. ${ }^{31}$

Furthermore, there are not statistics or indicators of pregnant women receiving prenatal care in Venezuela since 2013. ${ }^{32}$ Thousands of pregnant women do not have any type of prenatal care in Venezuela. ${ }^{33}$ During interviews with the United Nations' High Commissioner for Refugees (UNHCR) in July 2019, some of them had reported serious deficiencies at their hospitals - there was no electricity, there were no physicians available for appointments, and there were not ultra-sound services. Also, women have faced corrupt practices: in many cases, they are asked significant amounts of money to receive health care, which they cannot pay. Additionally, many women fear for the lives of their children. Some hospitals in Venezuela have been under investigation for child deaths, causing their closure and leaving geographical areas without access to health care. ${ }^{34}$

A significant example is the Maternidad Concepción Palacios Hospital, located in Caracas, Venezuela, which covers forty percent of the national maternal health care, where pregnant women face various risks, such as long delays, difficulties in obtaining and preserving plasma, the absence of equipment for biopsies and other procedures essential for

31 Angelika Albaladejo, "Contraceptive Shortages Mean Venezuela's People Face a Sexual Health Emergency,” British Medical Journal 360, No. 1197 (2018), https://doi. org $/ 10.1136 /$ bmj.k1197

32 According to the World Bank Open Data, there are none indicators. World Bank, Indicator of pregnant women receiving prenatal care (\%) - Venezuela, accessed March 9, 2020, https://data.worldbank.org/indicator/SH.STA.ANVC.ZS?end=2013\&locations=VE $\&$ start $=2000 \&$ view $=$ chart.

33 HRW and JHSPH, Venexuelas Humanitarian Emergency..., 34.

34 Alejandra, "Mujeres embarazadas huyen de la falta de atención...;" Inter-American Commission of Human Rigths [IACHR]. "Maternidad Concepción Palacios Hospital regarding Venezuela.” Precautionary Measure No. 150-19, Res. 13/2019 (March 18, 2019), para. 7, https://www.oas.org/es/cidh/decisiones/pdf/2019/13-19MC15019-VE.pdf 
the detection of cervical cancer and other prenatal issues, the lack of gel for ultrasounds, an insufficiency in specialists like anesthesiologists and gynecologists, and insufficient capacity for a high number of deliveries, shortages in beds in delivery rooms. Also, this hospital faces situations like women giving birth in waiting rooms or outside the hospital. An employee from the hospital said that when children require any special treatment at birth, they will most likely die quickly given the insufficient neonatal care. ${ }^{35}$ In only five months, from August to December of 2018, fifteen women and 265 newborns died in that hospital. ${ }^{36}$ Given this dire situation for pregnant women in Venezuela, they have fled to Colombia searching for health care.

\subsection{Cross-Border Migration to Colombia in Search of Health Care}

Colombia is the primary host country for Venezuelan migrants, having received 1408055 Venezuelans as of June 30, 2019. ${ }^{37}$ There are around 679203 migrant women from Venezuela, ${ }^{38}$ of whom many of them face challenges accessing health care. ${ }^{39}$ According to the Colombian government, more than 8200 pregnant women had entered Colombia, from which the majority, around 6300, have not received any type of prenatal care. ${ }^{40}$ Different border cities have reported hundreds of high-risk

\footnotetext{
35 IACHR. "Maternidad Concepción Palacios Hospital...," para. 7.

36 Ibid., para. 6.

37 Migración Colombia, "Historical statistics." Migración Colombia, August 1, 2019, 2, https://www.migracioncolombia.gov.co/infografias/231-infografias-2019/total-devenezolanos-en-colombia-corte-a-30-junio-de-2019

38 Ibid., 5.

39 HRW and JHSPH, Venexuelas Humanitarian Emergency..., 34.

40 Ministerio de Salud y la Protección Social de Colombia, Plan de respuesta del sector salud al fenómeno migratorio, accessed April 27, 2020, https://www.minsalud.gov.co/sites/rid/ Lists/BibliotecaDigital/RIDE/DE/COM/plan-respuesta-salud-migrantes.pdf; Nicolás Marín, “¿Qué pasa en Colombia con las venezolanas embarazadas?” El Espectador, July 21, 2018, https://www.elespectador.com/noticias/el-mundo/que-pasa-en-colombia-conlas-venezolanas-embarazadas-articulo-801453; HRW and JHSPH, Venexuelas Humanitarian Emergency..., 34.
} 
pregnancies $^{41}$ due to anemia, sexually transmitted diseases, complications during labor, and hazardous journeys into Colombia, among other reasons. For example, Save the Children opened a clinic in Maicao, La Guajira, a border city in Colombia; the clinic received 792 pregnant women between April and July 2019, of whom sixty-one percent were experiencing high-risk pregnancies. ${ }^{42}$

Although "pregnancy can be circumstantial to the migration process (...) in some cases it can motivate migration in search of better health care, especially in a context of food and medicine shortages, like the one happening in Venezuela, apparently is the process in the border" 43 with Colombia. Many pregnant women wait until the second and third trimester to migrate to Colombia to search for health care. ${ }^{44}$ Often they are unaware of the dangers in the journey, ${ }^{45}$ and some of them are in severe malnutrition conditions before making the journey. ${ }^{46}$

For instance, in Cúcuta, Norte de Santander, another Colombian border city, forty-five Venezuelan women experienced pregnancy or childbirth-related severe illness; seven of them died in 2018. Besides, there is an increase in low birth weight and perinatal or neonatal mortality among Venezuelan children in Colombia, from four in 2015 to 211 in

41 Julián Fernández-Niño et al., "Situación de salud de gestantes migrantes venezolanas en el Caribe colombiano: primer reporte para una respuesta rápida en Salud Pública," Revista de la Universidad Industrial de Santander 51, (2019): 208-2019, http://www.scielo. org.co/pdf/suis/v51n3/0121-0807-suis-51-03-208.pdf

42 Save the Children, Hundreds of Heavily Pregnant Venezuelan Women Seek Treatment at Save The Children Colombian Border Clinic, July 10, 2019, https://www.savethechildren.net/ news/hundreds-heavily-pregnant-venezuelan-women-seek-treatment-save-childrencolombian-border-clinic

43 Fernández-Niño et al., "Situación de salud de gestantes migrantes venezolanas...", 209.

44 Henao et al., "Calidad de vida percibida de las madres gestantes venezolanas...".

45 Notimérica, "Cientos de mujeres y adolescentes venezolanas embarazadas cruzan a Colombia en busca de atención médica," Notimérica, July 10, 2019, https://www.notimerica.com/sociedad/noticia-cientos-mujeres-adolescentes-venezolanas-embarazadascruzan-colombia-busca-atencion-medica-20190710192053.html

46 According to a recent National Survey on Living Conditions in Venezuela, forty-nine percent of pregnant women suffer from moderate to severe malnutrition in Venezuela.

Luisa F. Freier and Nicolas Parent, "The Regional Response to the Venezuelan Exodus," Current History 118, (2019): 56-61, https://www.academia.edu/39166992/ The_Regional_Response_to_the_Venezuelan_Exodus. 
2018. There is an obvious demand for health care from pregnant women, reflecting the unavailability of care in Venezuela and the increase in deliveries among women with insufficient prenatal care. In 2018, the university hospital in Cúcuta reported 2944 births of children with Venezuelan parents. ${ }^{47}$

After the massive influx of Venezuelans, including pregnant women, Colombia has enacted some national laws to provide emergency health care to migrants.

\subsection{Colombia's Measures to Provide Health Care to Venezuelan Migrants}

The Colombian government has implemented different measures to provide emergency health care ${ }^{48}$ for Venezuelan migrants in general. ${ }^{49}$ For pregnant migrants, in particular, medical procedures related to labor and pregnancy complications are considered emergencies, but prenatal and postnatal care are not considered. ${ }^{50}$ Given that most pregnant women arrive in Colombia in critical conditions because of the advanced-term pregnancies and the medicines and prenatal care lacks, most cases require urgent care. ${ }^{51}$ However, Venezuelan pregnant women cannot receive

47 HRW and JHSPH, Venexuelas Humanitarian Emergency..., 35.

48 In Colombia, the Decree 412/1992 defines emergency health care as the initial urgent attention to a person with an alteration of the physical and/or mental integrity caused due to trauma or disease of any etiology that generates a demand for immediate and effective medical attention aimed at reducing the risks of disability and death.

49 According to Article 168 of L. 100/1993, every public or private entity that provides health services is obligated to provide emergency health care to every person regardless their payment capacity.

50 Diana Gomez, Gloria Gonzalez y Claudia Tabares, Embarazo y migración: percepción de mujeres gestantes venezolanas sobre acceso a servicios de salud, red-salud Armenia-Colombia, (Specialist diss., Fundación Universitaria del Área Andina, 2019), https://digitk.areandina. edu.co/bitstream/handle/areandina/3411/Embarazo $\% 20 y \% 20$ migración $\% 20 \% 20$ percepción $\% 20 \mathrm{de} \% 20$ mujeres $\% 20$ gestantes $\% 20$ venezolanas $\% 20$ sobre $\% 20$ acceso $\% 20$ a $\% 20$ servicios $\% 20$ de $\% 20$ salud $\% 2$ C $\% 20$ Red-Salud $\% 20$ Armenia $\% 20-\% 20$ Colombi. pdf? sequence $=1 \&$ is Allowed $=\mathrm{y}$

51 Nicolas Maín, “¿Qué pasa en Colombia con las venezolanas embarazadas?”, El Espectador, July 21, 2018, https://www.elespectador.com/mundo/america/que-pasaen-colombia-con-las-venezolanas-embarazadas-article-801453/ 
prenatal and postnatal care in Colombia because, for example, medical specialties and diagnostic tests are not considered emergencies. ${ }^{52}$

The social security system in Colombia allows migrants to access health care under different conditions. If the person has a regular immigration status and has a formal job, she has access to health care paying coverage. If the person has a regular immigration status and does not have a formal job, she has access to health care only for medical emergencies, or she can follow a process to access subsidized coverage. Finally, if the person has irregular immigration status, including people without any identification document, she has only access to emergency care. ${ }^{53}$ Thus, numerous pregnant migrants can only access emergency health care given that they do not have formal jobs nor a regular immigration status, a situation that can be different in other countries. ${ }^{54}$ For example, Chile reformed its immigration policies in 2015 to provide health care to Venezuelan migrants. If a person is a refugee, a child, or a pregnant woman, they can access health care notwithstanding their immigration status, and they can even apply for a temporary visa. In particular, with the influx of Venezuelan pregnant women, Chile decided to provide prenatal and postnatal care until twelve months after birth. ${ }^{55}$

Although Colombia has created a special permit to provide regular immigration status for Venezuelans, and this permit is supposed to enable them to work, study, and have health care, the access to health care still depends on them having a formal job or following a very hard process

\footnotetext{
52 Gomez et al., Embarazo y migración..., 41.

53 Ministerio de Salud y la Protección Social de Colombia, Plan de respuesta del sector salud..., 28; José Koechlin y Joaquín Eguren, "El éxodo venezolano: entre el exilio y la emigración," OBIMID 43, (2018), http://repositorio.uarm.edu.pe/bitstream/UNIARM $/ 2031 / 1 / \mathrm{El} \% 20 \% \mathrm{C} 3 \%$ A 9 xodo $\% 20$ venezolano $\% 20 \% 20$ entre $\% 20$ el $\% 20$ exilio $\% 20$ $\mathrm{y} \% 201 \mathrm{a} \% 20$ emigraci $\% \mathrm{C} 3 \% \mathrm{~B} 3$ n.pdf $\#$ page $=21$

54 Most of the emergency health care for Venezuelan migrants has been focused on emergency health care for giving birth and child vaccination.

Fernández and Orozco. "Migración venezolana en Colombia: retos en salud pública," Revista de la Universidad Industrial de Santander 50 (2018): 5-6, https://revistas. uis.edu.co/index.php/revistasaluduis/article/view/7992

55 Alexander Grubessich y Monserrat Sepúlveda, Derecho a la saludpara los inmigrantes en Chile. Normativa, estándares y problemas de acceso y atención, (Universidad de Chile, Bachelor diss., 2020), http://repositorio.uchile.cl/bitstream/handle/2250/174822/Derecho-ala-salud-para-los-inmigrantes-en-Chile-normativa-estandares-y-problemas-de-acceso. pdf? sequence $=1 \&$ is Allowed $=\mathrm{y}$
} 
for subsidized health care ${ }^{56}$ Moreover, the special permit is limited to migrants that arrived in Colombia before 2019 through a regular point of entry with a passport (Res. No. 5797/2017).

Finally, the Colombian health ministry has published a response plan prioritizing pregnant women and children. This prioritization is only for services related to highly transmissible infections and diseases, medical care in cases of gender violence, and chronic conditions that worsen during migration. Also, the plan stated that these services should consider vaccination and contraception. At the same time, this plan provides that measures have to be taken progressively but are limited to the sustainability of the social security system in general. The implementation of these measures depends on the particular decisions of individual territorial entities rather than the national government because it is not legally binding as law.

Although Colombia's national laws and implementation plans may be underserving of pregnant migrants regarding integral health care, international law may offer them additional protection. The following section addresses the question of applicable international laws and concludes that pregnant women fleeing Venezuela can meet refugee requirements, and Colombia has the obligation to implement progressive reproductive health care measures.

\section{The International Legal Framework Regarding Colombia's Human Rights Obligations to Provide Reproductive Health Care for Pregnant Refugees}

Colombia has become the primary host country for Venezuelan migrants, for which it has implemented different measures to address what has become a migratory crisis. The regularization status process and the inclusion of the immigration crisis as part of the national development plan by the Colombian government was recognized as an example in the region by the UNHCR, Filippo Grandi. ${ }^{57}$ However, the situation is dire.

\footnotetext{
56 Ministerio de Salud y la Protección Social de Colombia, Plan de respuesta del sector salud...

57 In 2018, the UNHCR, Filippo Grandi, visited Argentina, Colombia, Ecuador, and Perú, which are the primary host countries for Venezuelan migrants. After his visit, he held a press conference in which he affirmed that Colombia had been an example in the region. He expressly referred to the regularization process of special permits
} 
Venezuelans struggle to survive in Colombia. ${ }^{58}$ For pregnant women, these circumstances exacerbate because they face significant risks, including triple discrimination (as women, migrants, and girl children), ${ }^{59}$ the likelihood of suffering health problems, and gender-based violence. ${ }^{60}$ Therefore, Colombia's human rights obligations offer a means to analyze this issue and assess its measures to address the immigration of thousands of pregnant women. Many international instruments have provisions regarding migrants' rights and the right to health. Still, this section focuses on the Cartagena Declaration and the American Convention on Human Rights (ACHR) because they are the most closely linked to Colombia, the nation-state under review.

and the inclusion of migrants as part of the national development plan by the national government.

See, Filippo Grandi, Filippo Grandi ofrece balance de su visita a Colombia, October 8, 2018, https://www.youtube.com/watch?v=YHnlVnxaG00; ACNur, El Alto Comisionado de las Naciones Unidas para los Refugiados, Filippo Grandi, visitará Colombia, Argentina, Ecuador y Perú, October 5, 2018, https://www.acnur.org/noticias/press/2018/10/5bb8098b4/ el-alto-comisionado-de-las-naciones-unidas-para-los-refugiados-filippo.html

58 Steven Grattan, “'Living a daily tragedy': Venezuelans struggle to survive in Colombia," The Guardian, November 1, 2019, https://www.theguardian.com/globaldevelopment/2019/nov/01/living-a-daily-tragedy-venezuelans-struggle-to-survive-incolombia; Marco Rotunno, Venezuelans living in the streets find safety at new reception center in Colombia, April 15, 2019, https://www.unhcr.org/news/stories/2019/4/5cb48f934/ venezuelans-living-streets-find-safety-new-reception-centre-colombia.html; Anastasia Moloney, "Desperate Venezuelan migrants face homelessness as Colombia's camp closes," Reuters, October 24, 2018, https://www.reuters.com/article/us-colombiavenezuela-migrants-feature/desperate-venezuelan-migrants-face-homelessness-ascolombias-camp-closes-idUSKCN1MY2GF

59 Notimérica, "Cientos de mujeres y adolescentes venezolanas embarazadas cruzan a Colombia..."

60 Laura Cruz, "El doloroso parto de las venezolanas en Colombia," El Espectador, January 14, 2020, https://www.elespectador.com/noticias/nacional/el-dolorosoparto-de-las-venezolanas-en-colombia-articulo-899757; Marta Martinez, "Inside the Colombian 'war hospital' treating Venezuela's pregnancy crisis." The New Humanitarian, November 27, 2019, https://www.thenewhumanitarian.org/news-feature/2019/11/27/ Venezuela-Colombia-pregnant-women-birth-reproductive-rights-migration-Cucutamaternal-care-migrants-refugees 


\subsection{The Cartagena Declaration on Refugees Expanded Refugee Definition}

The Cartagena Declaration on Refugees ${ }^{61}$ is a regional instrument adopted in 1984 by delegates from ten Latin American countries: Belize, Colombia, Costa Rica, El Salvador, Guatemala, Honduras, Mexico, Nicaragua, Panama, and Venezuela. ${ }^{62}$ The Cartagena Declaration resulted from the Colloquium on International Protection for Refugees and Displaced Persons in Central America, Mexico, and Panama, which was held in Cartagena, Colombia, on November 22, 1984, as an answer to the massive influx into each of the signatory countries of Central American refugees. ${ }^{63}$ The Cartagena Declaration resulted in some conclusion paragraphs and recommendations to states.

The primary purposes of the Cartagena Declaration were to recognize the legal and humanitarian problems affecting people displaced by violence and conflict, and therefore to harmonize the regional refugee protection framework. ${ }^{64}$ Although the Cartagena Declaration only recommends the use of the expanded definition and does not create

61 Cartagena Declaration on Refugees, accessed May 1, 2020, https://www.unhcr.org/ about-us/background/45dc19084/cartagena-declaration-refugees-adopted-colloquiuminternational-protection.html

62 On December 2-3, 2014, the Latin American countries met in Brasilia (Brazil) for the 30th anniversary of the Cartagena Declaration. At the end of the meeting, twentyeight States and three territories adopted by acclamation the Declaration and the Action Plan Brasilia, encouraging the adoption of the Cartagena Declaration definition of a refugee.

Brazil Declaration, A Framework for Cooperation and Regional Solidarity to Strengthen the International Protection of Refugees, Displaced and Stateless Persons in Latin America and the Caribbean, December 3, 2014, https://www.acnur.org/fileadmin/Documentos/ BDL/2014/9865.pdf

Additionally, Bolivia, Ecuador, México, Belice, Brasil, Guatemala, Paraguay, El Salvador, Perú, Honduras, Argentina, Uruguay, Nicaragua, Colombia, Chile, and Costa Rica have incorporated the Cartagena Declaration into national law.

ACNur, Definición Regional de Refugiado: Paises de américa Latina que la han incorporado a su legislación nacional, accesed April 28, 2020, https://www.acnur.org/fileadmin/ Documentos/Proteccion/Buenas_Practicas/9183.pdf?view $=1$

63 IACHR, Human Mobility: Inter-American Standards, OEA/Ser.L/V/II., Doc. 46/15, December 31, 2015. http://www.oas.org/en/iachr/reports/pdfs/HumanMobility.pdf

64 Cartagena Declaration, para. 1; United Nations High Commissioner for Refugees [UNHCR]. "Summary conclusions on the Interpretation of the extended refugee

ACDI, Bogotá, ISSN: 2027-1131/ISSNe: 2145-4493, Vol. 15, pp. 223-265, 2022 
a binding obligation, at least fourteen states have incorporated it into national laws and state practice, including Colombian law —article 1, Decree No. 2840 of 2013 - . The refugee definition extended the protection of the 1951 Convention relating to the Status of Refugee ${ }^{65}$ and its 1967 Protocol $^{66}$ adding other situations that could motivate forced migration, as follows:

Hence the definition or concept of a refugee to be recommended for use in the region is one which, in addition to containing the elements of the 1951 Convention and the 1967 Protocol, includes among refugees persons who have fled their country because their lives, safety, or freedom have been threatened by generalized violence, foreign aggression, internal conflicts, massive violation of human rights or other circumstances which have seriously disturbed public order. ${ }^{67}$

The expanded definition was a recommendation of the InterAmerican Commission on Human Rights (IACHR) to member states of the Organization of American States in its annual reports of 1981-1982. ${ }^{68}$ Therefore, the Cartagena Declaration recognizes in its text the doctrine of the inter-American human rights system as a basis for its expanded definition. The countries endorsing the Cartagena Declaration stated

definition contained in the 1984 Cartagena Declaration on Refugees." Expert roundtable, Montevideo (Uruguay), October 15-16, 2013, https://www.unhcr.org/53bd4d0c9.pdf 65 Convention relating to the Status of Refugees, July 28, 1951, 189 U.N.T.S. 137 [1951 Convention], https://www.unhcr.org/3b66c2aa10

This treaty, which entered into force on Apr. 22, 1954, has 146 parties; among them is Colombia, which ratified on Oct. 10, 1961.

See UNHCR, States parties, reservations and declaration, September, 2019, https://www. unhcr.org/5d9ed32b4

66 Protocol Relating to the Status of Refugees, Jan. 31, 1967, 606 U.N.T.S. 267 [1967 Protocol], https://www.unhcr.org/3b66c2aa10

This protocol, which entered into force on Oct. 4, 1967, has 147 parties; among them is Colombia, which ratified on Mar. 4, 1980. See UNHCR, States parties, reservations and declaration.

67 Cartagena Declaration, para. 3.

68 IACHR. Annual Report of 1981-1982, OEA/Ser.L/V/Ll.57 Doc. 6 rev.1, September 20, 1982. Accessed May 2, 2020, https://www.acnur.org/fileadmin/Documentos/ BDL/2001/4395.pdf 
its robust relationship with the inter-American system by establishing the need "to promote greater use of the competent organizations of the inter-American system (...) with a view to enhancing the international protection of $(. .$.$) refugees." 69$

The Cartagena Declaration highlights the importance of human rights. First, it recognizes the principle of non-refoulment as a jus cogens rule that must be observed by states; this means that migrants cannot be rejected at the frontier. ${ }^{70}$ Second, it reiterates the voluntary and individual character of repatriation and the principle of family reunification. ${ }^{71}$ Finally, it acknowledges the economic, social, and cultural rights of refugees and the importance of integrating refugees into the country by concluding

To make a study, in countries in the area which have a large number of refugees, of the possibilities of integrating them into the productive life of the country by allocating to the creation or generation of employment the resources made available by the international community through UNHCR, thus making it possible for refugees to enjoy their economic, social and cultural rights.

Moreover, the Inter-American Court of Human Rights (IACtHR) held in the advisory opinion OC-21 of 2014 that "the obligations under the right to seek and receive asylum are operative with respect to those persons who meet the components of the expanded definition of the Cartagena Declaration." 72 In this opinion, the IACtHR identifies the rights and guarantees of children in the context of migration and in need of international protection and wrote that the Cartagena Declaration is part of the corpus iuris for the protection of children that are asylum seekers and refugees. ${ }^{73}$ Thus, the IACtHR recognizes that the Cartagena

\footnotetext{
69 Declaración de Cartagena, 1984, para. 15.

70 Ibid., para. 5.

71 Ibid., para. 12.

72 Inter-American Court of Human Rights [IACtHR]. Rights and Guarantees of Children in the Context of Migration and/or in need of International Protection, Advisory Opinion, OC-21/14, (Ser. A) No. 21, August 19, 2014, para. 79.

73 Ibid., para. 249.
} 
Declaration is a response to the forced movement dynamic and the regional protection challenges. ${ }^{74}$

Additionally, the IACHR has contended, in the Inter-American Standards on Human Mobility report of 2015, that the refugee status is declarative, not constitutive, which means that a person is a refugee when she/he meets the requirements of the definition without the need for formal recognition by some authority. ${ }^{75}$

Under the Cartagena Declaration, international protection must be granted in the presence of two types of risks: group-based risks, such as the persecution grounds under the 1951 Convention and its 1967 Protocol, and situational risks, related to five "situational events" under the Cartagena Declaration's expanded definition.

The UNHCR often organizes expert meetings to examine developments in refugee law and emerging issues. The expert meetings can include the government, non-governmental organizations, academia, judiciary, and the legal profession. ${ }^{76}$ After an expert meeting in Montevideo, Uruguay, on October 15-16, 2013, the UNHCR published the summary conclusions on the interpretation of the extended refugee definition under the Cartagena Declaration. In these conclusions, the UNHCR interpreted that the situational risks included in the definition are indiscriminate, unpredictable, or collective for the people. Also, the meeting concluded that the Cartagena Declaration includes the indirect effects of those situational events, such as poverty, inflation, economic decline, violence, food insecurity, disease, malnourishment, and displacement. ${ }^{77}$

Consequently, a person may qualify as a refugee under the extended definition if $\mathrm{s} /$ he is outside her/his country; her/his country is experiencing at least one of the five situational events, and her/his life,

\footnotetext{
74 Ibid., para. 79.

75 IACHr. Human Mobility: Inter-American Standards, OEA/Ser.L/v/II., Doc. 46/15, December 31, 2015, para. 131, http://www.oas.org/en/iachr/reports/pdfs/HumanMobility. pdf

76 unhCr, Department of International Protection Experts Meetings, February 19, 2014, https://www.unhcr.org/protection/expert/3e5f78bc4/expert-meetings.html

77 UNHCR, "Summary conclusions on the Interpretation of the extended refugee definition contained in the 1984 Cartagena Declaration...," para. 9.
} 
security, or freedom is threatened or at risk, as result of the situational event in that country. ${ }^{78}$

The Venezuelan migration crisis has been related to situational events, in particular to massive violations of human rights as well as other circumstances that have seriously disturbed public order. ${ }^{79}$ Pregnant women that flee to Colombia due to the health system crisis might be refugees if the health crisis has caused massive violations of their reproductive rights and disruption of public order, which threatens their life, security, or freedom. Therefore, this paper now turns to describe these two possible situational events.

\subsubsection{Massive Violation of Human Rights as a Ground for Refugee Status}

The IACtHR has used massive violations of human rights to refer to the scale or magnitude of human rights violations. For example, in Rio Negro Massacres v. Guatemala, the IACtHR explained that it is not possible to identify all the victims in the case because "it concerns mass or collective violations." 80 This impossibility is also recognized as part of the IACtHR rules of procedures (article 35). Also, the UNHCR contended that massive violations include the contexts in which "the effects of the violations go beyond the actual/direct victims to reach other segments of the population or even the society as a whole." 81 Given these contextual elements, the forced displacement typically is a consequence of grave and extended violations of human rights. ${ }^{82}$

The 1989 International Conference on Central American Refugees prepared, with an expert group, an assessment of protection and assistance to refugees in Guatemala. The evaluation resulted in the

\footnotetext{
78 Ibid., para. 12.

79 Oriana van Praag, Understanding the Venezuelan refugee crisis, September 13, 2019, https://www.wilsoncenter.org/article/understanding-the-venezuelan-refugee-crisis

80 IACtHR, Artavia Murillo and others ("In Vitro Fertilization") v. Costa Rica, Preliminary Exceptions, Merits, Reparations, and Costs, Judgment, (Ser. C) No. 257, November 28, 2012, para. 257.

81 UNHCR, "Summary conclusions on the Interpretation of the extended refugee definition contained in the 1984 Cartagena Declaration...," para. 21.

82 Ibid.
} 
publication of the principles and criteria for the protection and assistance of Central American refugees, repatriates, and displaced people in Latin America. Among its conclusions, it asserted that massive violations of human rights are large-scale violations of human rights and fundamental freedoms. Therefore, massive violations of human rights also include the serious denial of civil, political, economic, social, and cultural rights. ${ }^{83}$

Moreover, in threatened democracy settings, the inter-American system has study massive violations of human rights from a social inequality and exclusion perspective. According to Victor Abramovich, these contexts reflect the degradation of institutional practices and the deficit of democratic States, leading towards new forms of human rights violations. ${ }^{84}$ Regarding the right to health, to evaluate a massive violation of human rights is necessary to consider the scale and the magnitude of cases, the victims' status, the impact, and the nature of the obligation. In general, it has been understood that failure to respect the right to health is a serious denial and a violation of human rights. ${ }^{85}$ Consequently, the degradation of health care as an institutional practice and policy can undermine the respect for health care access. For example, according to Amnesty International, it was impossible to access health care in the Democratic Republic of Congo in 2004 during a domestic conflict, which constituted right to health violations. ${ }^{86}$

83 International Conference on Central American Refugees. Principles and criteria for protection and assistance of Central American refugees, repatriates, and displaced people in Latin America, May 29-31, 1989, https://www.refworld.org/docid/4370ca8b4.html

84 Victor Abramovich, "De las violaciones masivas a los patrones estructurales: nuevos enfoques y clásicas tensiones en el sistema interamericano de derechos humanos," SUR 6, No. 11 (December 2009): 7-39. https://www.corteidh.or.cr/tablas/r24902.pdf

85 Geneva Academy. What amounts to 'a serious violation of international human rights law'? An analysis of practice and expert opinion for the purpose of the 2013 Arms Trade Treaty, August, 2014, https://www.geneva-academy.ch/joomlatools-files/docman-files/Publications/Academy $\% 20$ Briefings/Briefing $\% 206 \% 20$ What $\% 20$ is $\% 20 \mathrm{a} \% 20$ serious $\% 20$ violation $\% 20$ of $\% 20$ human $\% 20$ rights $\% 20$ law_Academy $\% 20$ Briefing $\% 20$ No $\% 206 . p d f$ 86 Amnesty International, Las violaciones masivas constituyen una crisis de salud pública, October 2004, https://www.es.amnesty.org/en-que-estamos/noticias/noticia/articulo/ las-violaciones-masivas-constituyen-una-crisis-de-salud-publica/ 


\subsubsection{Other Circumstances Which Have Seriously Disturbed Public Order as a Ground for Refugee Status}

The 1989 International Conference on Central American Refugees concluded that other circumstances which have seriously disturbed public order "amount to no more than situations of internal disturbance and tensions, such as riots, isolated and sporadic acts of violence and other acts of a similar nature, as long as they seriously disturb public order." ${ }^{87}$

The International Committee of the Red Cross, in its commentaries regarding the protection of victims of non-international armed conflicts, has differentiated the internal disturbances from armed conflicts by explaining that those contexts can include a severe and prolonged confrontation with violence but without armed conflict. ${ }^{88}$ The disturbance may have various forms. For example, it includes situations in which the government authorities extensively mobilize their police forces or even army forces to restore internal order. Similarly, internal tensions include political, social, economic, and religious tensions, among others. These can involve large-scale arrests, political prisoners, missing people, inhuman detention conditions, suspension of judicial guarantees, and states of emergencies (de jure or de facto). Therefore, not only the use of force to prevent and preserve order is considered as disturbance or tension, but also the social and economic emergencies that involve the use of force. ${ }^{89}$

\subsubsection{Life, Security or Freedom Threatened or at Risk}

Considering those "situational events," a person is a refugee when that situation creates the possibility of harm if s/he returns to her/his country. Unlike the 1951 Convention, the Cartagena Declaration, by means of this element, does not require an individualized assessment of the risk. The expert meeting of the UNHCR regarding the expanded definition

\footnotetext{
87 International Conference on Central American Refugees. Principles and criteria for protection and assistance of Central American refugees, repatriates..., para. 33.

88 International Committee of the Red Cross. Commentary of 1987 on the Protocol Additional to the Geneva Conventions of 12 August 1949, and relating to the Protection of Victims of Non-International Armed Conflicts (Protocol II), 8 June 1977 (Commentary of 1987).

89 Ibid.; International Conference on Central American Refugees. Principles and criteria for protection and assistance of Central American refugees, repatriates..., para. 31-33.
} 
stated that "[i]n fact, proximity of - temporal and/or spatial/geographical - or imminence of the threat would suffice to justify the need for international protection under the Cartagena refugee definition." ${ }^{90}$ Also, the UNHCR concluded that, in most cases, the context and situation in the person's country would per se be such as to create the risk automatically. ${ }^{91}$

\subsection{The Right to Health of Refugees under the Inter-American System of Human Rights}

The Cartagena Declaration acknowledges the relationship between immigration status and the right to health by recommending to states the integration of refugees through the guarantee of their economic, social, and cultural rights. ${ }^{92}$ Similarly, the IACHR has also recognized the link between the right to health and migrants' status. ${ }^{93}$ For instance, in Andrea Mortlock $v$. the United States - the deportation of a Jamaican national living with AIDS/HIV-, the IACHR stated that removal to a place with sub-standard access to comparable health care could constitute punishment because the person could be left suffering, which could unnecessarily lead to premature death. Consequently, there would be a violation of due process under the American Declaration of Human Rights (ADHR) ${ }^{94}$ because the deportation proceedings have to answer "whether the deportation will create extraordinary hardship to the deportee (...) and may well amount to a death sentence."95

Also, the IACHRconcluded, in that case, that there was not a violation of the right to health under the ADHR because the United States did not deny access to medical care to Ms. Mortlock while being in the

\footnotetext{
90 UNHCR, "Summary conclusions on the Interpretation of the extended refugee definition contained in the 1984 Cartagena Declaration...," para. 28.

91 Ibid.

92 Cartagena Declaration, para. 11.

93 IACHR, Human Mobility: Inter-American Standards, OEA/Ser.L/v/II., Doc. 46/15, December 31, 2015, http://www.oas.org/en/iachr/reports/pdfs/HumanMobility.pdf

94 American Declaration of the Rights and Duties of Man [ADHR], O.A.S. Rex. Xxx, adopted by the Ninth International Conference of American States (Mar. 30-May 2, 1948), Bogotá, O.A.S. Off. Rec. OEA/Ser.L/v/I.4 Rev. (1965), https://www.cidh.oas. org/Basicos/English/Basic2.american\%20Declaration.htm

95 IACHR, Andrea Mortlock v. the United States, Case 12.534, Report No. 63/08, July 25, 2008, para. 95 .
} 
United States. However, this means that there can be a violation of the right to health under the ADHR when a state denies access to health care to a migrant based on its immigration status. In this particular case, the IACHR analyses the rights under the ADHR because the United States is not a party to the American Convention of Human Rights (ACHR). ${ }^{96}$

Unlike the United States, Colombia has ratified the ACHR. Although various inter-American instruments include the right to health, the only justiciable one under the inter-American system is the ACHR, which applies to refugees under its jurisdiction. The ACHR does not have an explicit provision for the right to health. However, the IACtHR has construed its article 26 to include this right as a justiciable one since $2018:^{97}$

The States Parties undertake to adopt measures, both internally and through international cooperation, especially those of an economic and technical nature, with a view to achieving progressively, by legislation or other appropriate means, the full realization of the rights implicit in the economic, social, educational, scientific, and cultural standards set forth in the Charter of the Organization of American States as amended by the Protocol of Buenos Aires.

According to the IACtHR in Poblete Vilches and others $v$. Chile about death for medical negligence, article 26 has two kinds of obligations. On the one hand, it includes the duty to adopt general measures to improve economic, social, and cultural rights progressively. On the other hand, it also consists of the obligation to take immediate action to guarantee access without discrimination to the benefits recognized for each right. ${ }^{98}$ Nevertheless, these obligations do not specify what is the content of the right to health.

\footnotetext{
96 American Convention on Human Rights[American Convention] (Adopted at the Inter-American Specialized Conference on Human Rights), Nov. 22, 1969, OAs Treaty Series No. 36, 1144 U.N.T.S. 123, https://www.cidh.oas.org/basicos/english/basic3. american $\% 20$ convention.htm

This treaty, which entered into force on July 18, 1978, has 23 parties; among them is Colombia, which ratified on July 31, 1973.

See U.N.T.C. https://treaties.un.org/pages/showDetails.aspx?objid $=08000002800 \mathrm{f} 10 \mathrm{e} 1$ 97 Inter-American Court of Human Rights (IACtHR). Poblete Vilches and others v. Chile, Merits, Reparations, and Costs, Judgment, (Ser. C) No. 349, March 8, 2018, para. 100.

98 Ibid., para. 104.
} 
The IACtHR has pointed out that the interpretation of the economic, social, and cultural rights included in article 26 must be the most favorable to the person. ${ }^{99}$ For the IACtHR, this means to harmonize the rights under the Charter of the Organization of American States, the ADHR, and the San Salvador Protocol. ${ }^{100}$

Thus, the IACtHR wrote in Five Pensioners v. Peru, regarding the reduction of the pension regime, that progressive development has to be measure based on the growing coverage of economic, social, and cultural rights in general, not particular, nor individual rights. ${ }^{101}$ Further, the IACtHr in Acevedo Buendía v. Peru (2009a), concerning discharged and retired employees, specified that article 26 include exigible rights that must be respected and guaranteed. In this case, the IACtHR concluded, quoting the United Nations Committee on Economic, Social, and Cultural Rights, that

the State shall have, mainly though not exclusively, an obligation to do, that is, to adopt provisions and provide the means and elements necessary to respond to the requirement for effectiveness of the rights in question, within the scope of the economic and financial resources the State has at its disposal to comply with the corresponding international commitment made. Hence, the progressive implementation of said measures may be subjected to accountability and, if applicable, compliance with the respective commitment assumed by the State may be demanded before instances called to decide on possible human rights violations. ${ }^{102}$

Moreover, the IACtHR explained that the states cannot adopt regressive measures. If they do so arguing limited resources, the IACtHR ruled that the measures have to be examined on a case-by-case basis.

99 IACtHR, González and others (“Cotton Field”) v. México. Preliminary Exceptions, Merits, Reparations, and Costs, Judgement, (Ser. C) No. 205 November 16, 2009.

100 Oscar Parra, La protección del derecho a la salud a través de casos contenciosos ante el sistema interamericano de derechos bumanos, accessed April 30, 2020, https://www.corteidh.or.cr/ tablas/r32459.pdf

101 IACtHr, Case of the "Five Pensioners" v. Peru, Merits, Reparations, and Costs, Judgement, (Ser. C) No. 98, February 28, 2003.

102 IACthr, Acevedo Buendía and others v. Peru, Preliminary Exceptions, Merits, Reparations, and Costs, Judgement, (Ser. C) No. 210, July 1, 2009, para. 102. 
In that case, the IACtHR would consider the following criteria: the country's development level, the seriousness of the infringement, the country's economic situation, the existence of other needs, the use of the least restrictive alternative, and the sought of cooperation and assistance. ${ }^{103}$ Aslo, the IACtHR recognized the argument made by the IACHR in the case of the National Association of Ex-Employees of the Peruvian Social Security Institute $v$. Peru of 2009. In that case, the IACHR established that regressive measures require an individual analysis because they require the most careful consideration, justification, and mensuration at the maximum of the resources available. ${ }^{104}$

Finally, in Cuscul Pivaral and others v. Guatemala (2018) regarding forty-nine people living with HIV, the IACtHR held that the right to health also has an immediate exigibility in relation to non-discrimination. Therefore, the right to health cannot be protected in a discriminatory fashion, particularly to health care benefits already recognized within the right to health.

Consequently, in Poblete Vilches and others $v$. Chile (2018), the IACtHR ruled that the right to health is fundamental and instrumental to other human rights. Therefore, every person has the right to enjoy the highest level of health to a dignified life, which means not only the absence of diseases or illness but also the complete physical, mental, and social well-being. ${ }^{105}$ In Hernández v. Argentina (2019), the IACtHR stated that states must guarantee access to quality and effective health care and promote the welfare of their population. In general, any medical care has to be accessible physically and economically with quality and without discrimination. Therefore, states have to pay special attention to vulnerable and marginalized groups. Additionally, in I.V.v. Bolivia (2016), the IACtHR recognized that the right to health includes sexual and reproductive health because it is an expression of well-being with particular implications in women. ${ }^{106}$

\footnotetext{
103 Ibid., para. 103.

104 Ibid., paras. 140-147.

105 IACthr, Poblete Vilches and others v. Chile, Merits, Reparations, and Costs, Judgment, (Ser. C) No. 349, March 8, 2018, para. 105.

106 IACthr, I.V. v. Bolivia, Preliminary Exception, Merits, Reparations, and Costs, Judgment, (Ser. C) No. 329, November 30, 2016, para. 157.
} 
The IACtHR has acknowledged that reproductive health includes the right to access medical care, information, education, and freedom to decide motherhood. The lack of legal safeguards about reproductive rights undermines reproductive autonomy and freedom. Additionally, the right to reproductive health involves the right to access pertinent medical care services. ${ }^{107}$

Although the IACtHR acknowledges that the measures taken under the right to health depend on the particular conditions of each state regarding resources and legislation, it established that compliance must give special care to vulnerable and marginalized groups and must be carried out progressively. ${ }^{108}$ Moreover, states must adopt domestic measures to guarantee the rights under the ACHR. Article 2 of the American Convention imposes this obligation in cases "where the exercise of any of the rights or freedoms (... like the right to health] is not already ensured by legislative or other provisions."

Considering the development of the right to health, under the inter-American system of human rights, which aims for its progressive protection, Colombia's national laws and implementation plans may violate human rights given their insufficiency to provide reproductive care to pregnant migrants.

\section{Colombia's Treatment of Pregnant Venezuelan Refugees Does Not Satisfy International Norms as Set Forth in the Inter-American Standards}

Colombia has human rights obligations and is facing many challenges as a receiving country of millions of Venezuelan migrants. One of these challenges is being the host of thousands of Venezuelan pregnant women seeking health care. ${ }^{109}$ This part of the paper argues that, despite the Colombian government's efforts to address the migration crisis and provide regular status for Venezuelans, the insufficiency to provide repro-

\footnotetext{
107 IACthr, Artavia Murillo and others (“In Vitro Fertilization”) v. Costa Rica, Preliminary Exceptions, Merits, Reparations, and Costs, Judgment, (Ser. C) No. 257, November 28, 2012, para. 146.

108 IACtHr, Hernández v. Argentina, Preliminary Exceptions, Merits, Reparations, and Costs, Judgment, (Ser. C) No. 395, November 22, 2019, para. 78.

109 Ministerio de Salud y la Protección Social de Colombia, Plan de respuesta del sector salud..., 23.
} 
ductive health care to Venezuelan pregnant women violates Colombia's human rights obligations in light of the "magnet", the "free rider," and the health care costs concerns related to migrants and refugees access to health care. Notably, this section states the need for refugee status recognition of Venezuelan pregnant women and their integral access to reproductive health care.

\subsection{Pregnant Venezuelan Women are Refugees under the Cartagena Declaration}

The Cartagena Declaration was meant to be a response to the Latin American context in which some countries have historically had hostile situations creating risk in life, security, and freedom. The Venezuelan socio-economic and political crisis cannot be an exception, mainly because the Cartagena Declaration recognizes the humanitarian and legal difficulties of displaced people and the importance of their economic, social, and cultural rights as part of their integration in host countries like Colombia. In this case, the pregnant women migrating from Venezuela to Colombia, as a result of the health crisis, are refugees, and they must have access to reproductive health in Colombia.

Pregnant Venezuelan women in Colombia are refugees because Venezuela is experiencing massive human rights violations and a health crisis that disturbs public order, and the life, security, and freedom of pregnant women are threatened as a result of the massive human rights violations and health crisis. ${ }^{110}$

\subsubsection{Context of Massive Human Rights Violations Affecting the Guarantee of Women's Reproductive Rights}

Currently, Venezuela has a context of massive human rights violations. Since the beginning of the socio-economic and political crisis in $2012,{ }^{111}$

\footnotetext{
110 Cartagena Declaration, para. 3; UNHCR, "Summary conclusions on the Interpretation of the extended refugee definition contained in the 1984 Cartagena Declaration...", para 12.

111 Melody Schreiber, Research are surprised by the magnitude of Venezuela's health crisis, April 5, 2019, accessed May 31, 2020, https://www.npr.org/sections/goatsandsoda/2019/04/05/709969632/researchers-are-surprised-by-the-magnitude-of-venezuelas-health-crisis
} 
thousands of human rights violations have been documented. In general, these human rights violations have been related to the massive protests in the country, specifically, to freedom of speech, expression, and association, including cases of arbitrary detention, torture, repression, and due process violations. ${ }^{112}$ Still, the health system crisis has also resulted in massive violations of the right to health. In particular, there is a degradation of health care due to an institutional failure to provide it, establishing new forms of structural and serious denial of human rights. ${ }^{113}$

The right to health situation is affecting society as a whole. It is impossible to identify all the victims of violations to their right to health, given its massive scale. In the case of pregnant women, they do not have any access to medical care, much less medical care of the quality required for healthy pregnancies and childbirth. At least thousands of women in pregnancy do not have any prenatal care in Venezuela. ${ }^{114}$ Also, health care is denied in numerous cases because of different reasons like the shortages in electricity and lack of personnel. Many women have reported corrupt practices that are barriers to access to health, which have to be economically and physically accessible. ${ }^{115}$ Similarly, some hospitals have closed, making it geographically impossible to access medical care. ${ }^{116}$

Different from most Latin American countries, Venezuela's disruption and deterioration of health care have been rapid and structural. ${ }^{117}$ The abrupt shortage and incapacity to provide essential health care institutionalize the denial and disregard of the right to health. Therefore, there is a context of massive violations of the right to reproductive health.

112 United Nations Office of the High Commissioner for Human Rights [OHCHR], Human rights violations in the Bolivarian Republic of Venezuela: a downward spiral with no end in sight, June 2018, https://www.ohchr.org/Documents/Countries/VE/VenezuelaReport2018_EN.pdf

113 Abramovich, "De las violaciones masivas a los patrones estructurales..."

114 HRW and JHSPH, Venequela's Humanitarian Emergency, 34.

115 IACthr, Hernández v. Argentina, Preliminary Exceptions, Merits, Reparations, and Costs, Judgment, (Ser. C) No. 395, November 22, 2019, paras. 69-82.

116 Alejandra Romo, Pregnant women fleeing the lack of health care in Venezuela, July 23, 2019, https://www.acnur.org/noticias/historia/2019/7/5d374bcb4/mujeres-embarazadashuyen-de-la-falta-de-atencion-medica-en-venezuela.html

117 HRW and JHSPH, Venezuela's Humanitarian Emergency. 


\subsubsection{Crisis of the Venezuelan Health System as a Result of Circumstances that Seriously Disturb Public Order}

There is political and socio-economic tensions in Venezuela, and the healthcare system crisis disturbs public order enormously. ${ }^{118}$ There are not health supplies and medicines, forcing some people to buy them in the black market or not being able to afford them. The percentages of shortage are excessively high in general, eighty-eight percent in medication, seventy-nine percent in surgical supplies, sixty-seven percent in electricity, and seventy percent in water, making it impossible for the system to respond to disease outbreaks. ${ }^{119}$ Moreover, the massive displacement of people also includes physicians, nurses, and any medical workforce, affecting the ability of the system to provide some services and affected specialty areas. ${ }^{120}$

Besides the use of force in the repression of protests and other contexts, the Venezuelan government has suppressed information, denied the crisis, and stopped publishing health data since 2017. These circumstances are signs of the existing tensions and disturbance, which expresses in the socio-economic, political, and humanitarian disruption in public order.

\subsubsection{The Threat to Life, Safety, and Freedom of Pregnant Women in Venezuela}

The high rates of maternal and child mortality, lack of capacity to provide reproductive health care in hospitals, and the absence of prenatal care threaten the life, safety, and freedom of Venezuelan pregnant women. The health crisis has already affected the lives of numerous women.

\footnotetext{
118 Ibid., 46.

119 Ibid., 15.

120 PAHO and WHO, Response for effective technical coordination in Venequela and neighboring countries." 162th Session of the Executive Committee, CE162/INF/22, June 18-22, 2018, para. 12. https://www.paho.org/hq/index.php?option=com_ docman\&view=download\&category_slug=162-en-9841\&alias $=45491$-ce162-inf-22e-paho-tc-respond-491\&Itemid $=270 \&$ lang $=$ en
} 
Only in one hospital, 15 pregnant women died in five months. ${ }^{121}$ Many more are at risk of infectious diseases, malnutrition, sexually transmitted infections, and other conditions that cannot be detected, given the lack of prenatal care. Additionally, the precariousness in reproductive health care affects the freedom and autonomy of women related to their right to health. As the IACtHRInter-American Court has recognized, the lack of guarantee of reproductive rights undermines autonomy and freedom with particular implications in women, causing marginalization and vulnerability. ${ }^{122}$

\subsection{Colombia's Government Must Adopt Measures to Guarantee Reproductive Health Care to Pregnant Refugees}

Given that Venezuelan pregnant women should be considered refugees under the Cartagena Declaration, the recognition of refugee status is essential to analyze the insufficient measures to provide reproductive health care. As the Cartagena Declaration states and the

IACHR recognizes, the right to health is linked to someone's immigration status. ${ }^{123}$ Currently, Colombia has adopted measures to provide the possibility of regularization, access to healthcare, and minimum emergency medical care. ${ }^{124}$ Nevertheless, the possibility of regularization has strict requirements that numerous pregnant women do not meet, the access to health care depends on a formal job, and the minimum emergency medical care is insufficient for the needs of pregnant women.

States such as Colombia face several issues and concerns that have historically limit migrants' and refugees' access to health care. These

\footnotetext{
121 IACHR "Maternidad Concepción Palacios Hospital regarding Venezuela." Precautionary Measure No. 150-19, Res. 13/2019 (March 18, 2019), para. 6, https://www.oas. org/es/cidh/decisiones/pdf/2019/13-19MC150-19-VE.pdf

122 IACthr, Artavia Murillo and others ("In Vitro Fertilization”) v. Costa Rica, Preliminary Exceptions, Merits, Reparations, and Costs, Judgment, (Ser. C) No. 257, November 28, 2012, para. 157; IACtHR, I.V. v. Bolivia, Preliminary Exception, Merits, Reparations, and Costs, Judgment, (Ser. C) No. 329, November 30, 2016, para. 147.

123 Cartagena Declaration, para. 11; IACHR, Human Mobility: Inter-American Standards, OEA/Ser.L/v/II., Doc. 46/15, December 31, 2015, para. 65, http://www.oas.org/en/ iachr/reports/pdfs/HumanMobility.pdf

124 Ministerio de Salud y la Protección Social de Colombia, Plan de respuesta del sector salud..., 28.
} 
issues and concerns are related to public health, humanitarian response, national economy, and immigration policy. ${ }^{125}$ Public health concerns point out that States find clinical, financial, economic, and social burdens in that providing health care can affect society as a whole, as refugees may often have unfamiliar infectious diseases, need regular care, require funding assistance, among others circumstances. ${ }^{126}$ At the same time, not only humanitarian but also ethical issues put States under scrutiny to provide health care to refugees in vulnerable situations. ${ }^{127}$

Also, one of the primary concerns is health care costs, which require evaluation of policies like "allowing no access, access only to emergency services, or access to preventive services, primary care, or secondary care". ${ }^{28}$ Finally, immigration policy concerns known as the "magnet" effect and the "free rider" concern are commonly related to the massive influx of migrants, meaning that provide health care would attract more of them (known as "welfare magnet") and that it could privilege them of a system that others have to pay for ("free rider").

Nevertheless, all of these concerns have upside as well ${ }^{129}$ or have been proven not to be empirical rather only political rhetoric. ${ }^{130}$ For example, providing health care for migrants and refugees can benefit the population in controlling outbreaks of infectious diseases; there is little evidence about the "magnet" concerns, and there are different immigration policy approaches that barely would increase health care costs. ${ }^{131}$

125 Bradford H. Gray and Ewout van Ginneken. "Health Care for Undocumented Migrants: European Approaches," Commonwealth Fund pub. 1650: Issues in International Health Policy 33 (December 2012).

126 Walden et al.,"Building Capacity to care for refugees." Fam Pract Manag. 24, No. 4 (July-August 2017): 21-27, https://www.aafp.org/fpm/2017/0700/p21.html

127 Mitchell Smith, "Health care for refugees." Asia Pacific Family Medicine 2 (January 2003): 71-73,https://citeseerx.ist.psu.edu/viewdoc/download?doi=10.1.1.471.9091\&re $\mathrm{p}=$ rep1\&type $=\mathrm{pdf}$

128 Gray and Ginneken, “Health Care for Undocumented Migrants...”, 3.

129 Ibid.

130 Scott Allard and Sheldon Danziger, "Welfare magnets: myth or reality?", The journal of politics 62, No. 2 (May 2000): 350-368, https://www.journals.uchicago.edu/doi/ pdf/10.1111/0022-3816.00016

131 Gray and Ginneken, "Health Care for Undocumented Migrants..."; Allard and Danzinger, "Welfare magnets: myth or reality?". 
Thus, there are ways to provide and improve access to health care for migrants and refugees. Different countries have implemented strategies and policies to progressively increase health care services, coverage, assistance, and quality. From a public health policy perspective, three dimensions of health care have been identified: "1) focusing on segments of the population, like children or pregnant women; 2) ocusing on types of services, like preventive services or treatment of infectious diseases, or 3) using specific funding policies, like allowing undocumented migrants to purchase insurance". ${ }^{132}$

Regarding all of the above, refugees' health care policies must implement a human rights approach that considers various strategies to deal with States' concerns. The right to health is so fundamental that it is instrumental to other human rights. The Inter-American Court explained that every person has the right to enjoy the highest level of health to a dignified life. ${ }^{133}$ For pregnant women, this means that they have the right to basic reproductive health care, which includes prenatal and postnatal services. The Inter-American Commission has considered that a denial of health care to a migrant can be a violation of the right to health. Considering that the right to health under the American Convention is a harmonization of different instruments, including the American Declaration, there could be a violation of the right to health under article 26 for denial of medical care. ${ }^{134}$ Therefore, there could be a human rights violation for denial of basic reproductive health care.

At the same time, the obligation under article 26 is to provide access to already recognized benefits of health care, which indicates that Colombia has the immediate obligation only to provide emergency health care already established under national laws. ${ }^{135}$ Nevertheless, article 26 also requires states to adopt progressive measures and prohibits regressive measures. Although this obligation depends on the particular condition and resources of Colombia, it has to be undertaken at the

\footnotetext{
132 Gray and Ginneken, “Health Care for Undocumented Migrants...”, 1.

133 IACthr, Hernández v. Argentina, Preliminary Exceptions, Merits, Reparations, and Costs, Judgment, (Ser. C) No. 395, November 22, 2019, paras. 69-82.

134 IACHR, Andrea Mortlock v. the United States, Case 12.534, Report No. 63/08, July 25,2008 .

135 IACthr, Cuscul Pivaral and others v. Guatemala, Preliminary Exceptions, Merits, Reparations, and Costs, Judgement, (Ser. C) No. 359, August 23, 2018.
} 
maximum resources available. For instance, the Response Plan adopted by the Health Ministry of Colombia prioritizes pregnant women and children for particular services. However, these services were already considered emergencies. Therefore, they cannot be characterized as a progressive measure.

Finally, the obligations under article 26 are subject to accountability on a case-by-case basis. Colombia should consider whether it is creating an extraordinary hardship for Venezuelan pregnant women in general, aiming to avoid the violation of individual rights in future cases. At the very least, the Colombian government should consider the progressive standard to provide reproductive health care that is related to dignity, with measures to ensure access, quality, and effectiveness. ${ }^{136}$ Hence, this has greater importance considering that the obligations under article 26 require states to pay special attention to vulnerable and marginalized groups like women, who suffer particular implications in the lack of guarantee of reproductive health. Consequently, Colombia must put into consideration measures such as education and information regarding reproductive care.

\section{Conclusion}

The Venezuelan health crisis is causing pregnant women to flee to Colombia in search of reproductive health care. In general, the Venezuelan health system is facing serious disruption and deterioration due to infrastructure, human resources, shortages, and data concerns. Against the progressive improvement in health care in most Latin American Countries, Venezuela has deeply and rapidly fallen into a structural denial of care. Unlike Colombia, in Venezuela maternal and child mortality rates are the worse compared to the region; the official data is not updated nor publish; the vaccination coverage is insufficient; the basic contraception distribution is nonexistent; the pregnant women are not receiving prenatal or postnatal care, and hospitals deny reproductive health care or risk women seeking care. Moreover, the lack of indicators suggests that the situation is dire.

\footnotetext{
136 IACtHr, Hernández v. Argentina, Preliminary Exceptions, Merits, Reparations, and Costs, Judgment, (Ser. C) No. 395, November 22, 2019, paras. 69-82.
} 
As has been documented by researchers, international organizations, and non-governmental organizations, the immigration of pregnant women to Colombia is mainly motivated by the need for health care and the fear for the life of their children and their own. In Colombia, most pregnant women arrive in irregular immigration status and with high-risk pregnancies. The government has made efforts to provide Venezuelans regularization and provide emergency health care. These migrants' and refugees' health care policies are based on issues and concerns related to public health, humanitarian response, national economy, and immigration policy.

However, Colombia's measures not only are insufficient in that these Venezuelans cannot access reproductive health care such as prenatal and postnatal care but also seem part of political rhetoric rather than evidence-based justifications. Comparing to other countries and following scholars in public health, States should consider other dimensions like provide health care focusing only on particular segments of the population. To study those possibilities, human rights obligations should be a fundamental factor in deciding whether or not to provide health care.

Under Colombia's human rights obligations, Venezuelan pregnant women are refugees, given the expanded definition in the Cartagena Declaration. Most pregnant women are fleeing Venezuela because they fear for the life of their children and themselves in a context of serious denial of health care that massive violates the right to health and disrupts public order. In other words, many of them that arrived with severe illnesses and malnutrition conditions could have died in Venezuela, requiring international protection such as refugee status in Colombia.

As refugees, the Colombian government should formally recognize their refugee status and adopt measures to provide quality, effective, and accessible reproductive health care. At least, this health care must include prenatal and postnatal to guarantee a dignified life. As part of its obligations to adopt progressive measures, the government must adopt legislative and executive steps that allow Venezuelan pregnant women to access medical services, information, education, and contraception.

\section{References}

Abramovich, Victor. "De las violaciones masivas a los patrones estructurales: nuevos enfoques y clásicas tensiones en el sistema 
interamericano de derechos humanos." SUR 6, No. 11 (2009): 7-39. https://www.corteidh.or.cr/tablas/r24902.pdf

ACNUR. El Alto Comisionado de las Naciones Unidas para los Refugiados, Filippo Grandi, visitará Colombia, Argentina, Ecuador y Perú. October 5, 2018. https://www.acnur.org/noticias/press/2018/10/5bb8098b4/ el-alto-comisionado-de-las-naciones-unidas-para-los-refugiadosfilippo.html

Albaladejo, Angelika. "Contraceptive Shortages Mean Venezuela's People Face a Sexual Health Emergency." British Medical Journal 360, No. 1197 (2018), https://doi.org/10.1136/bmj.k1197

Allard, Scott and Sheldon Danziger. "Welfare Magnets: Myth or Reality?" The Journal of Politics 62, No. 2 (2000): 350-68, https://www. journals.uchicago.edu/doi/pdf/10.1111/0022-3816.00016

American Convention on Human Rights, November 22, 1969. OAS Treaty Series No. 36, 1144 U. N. T. S. 123.

Amnesty International. "Las violaciones masivas constituyen una crisis de salud pública.", October 26, 2004, https://www.es.amnesty. org/en-que-estamos/noticias/noticia/articulo/las-violacionesmasivas-constituyen-una-crisis-de-salud-publica/

Ayala, Jhorland. "La salud en Colombia: más cobertura pero menos acceso." Banco de la república de Colombia, No. 204 (2004), https:// www.banrep.gov.co/sites/default/files/publicaciones/archivos/ dtser_204.pdf

Bertrand, Jane T., Roberto Santiso-Gálvez, and Victoria M. Ward. "Planificación familiar en Colombia: logros de 50 años." Measure Evaluation. https://www.measureevaluation.org/resources/publications/sr-15-118a-es/at_download/document

Cartagena Declaration on Refugees. November 22, 1984.

Carrillo, Alejandra. "Sistema de salud en Venezuela: ¿un paciente sin remedio?" Cadernos de Saúde Pública-Reports in Public Health 34, No. 3 (March 2018). https://doi.org/10.1590/0102-311X00058517

Colombia, Ministerio de Relaciones Exteriores. Resolución No. 5797/ 2017. July 25, 2017.Cruz, Laura. "El doloroso parto de las venezolanas en Colombia." El Espectador, January 14, 2020, https:// www.elespectador.com/noticias/nacional/el-doloroso-parto-delas-venezolanas-en-colombia-articulo-899757

Colombia, Ministerio de Salud y de la Protección Social. Afiliación al sistema general de seguridad social en salud de extranjeros y colombianos retornados. Accessed May 1, 2020. https://www.minsalud.gov.co/ 
proteccionsocial/Paginas/afiliacion-al-sistema-de-seguridadsocial-en-salud-de-extranjeros-y-colombianos-retornados.aspx

Colombia, Ministerio de Salud y de la Protección Social. Plan de respuesta del sector salud al fenómeno migratorio. Accessed April 27, 2020. https:// www.minsalud.gov.co/sites/rid/Lists/BibliotecaDigital/RIDE/ $\mathrm{DE} / \mathrm{COM} /$ plan-respuesta-salud-migrantes.pdf

Fernández-Niño, Julián, Maylen Rojas, Ietza Bojorquez, Vanesa Giraldo, Rita Sobezyk, Jorge Acosta, Victor Flórez, and David Rodríguez. "Situación de salud de gestantes migrantes venezolanas en el Caribe colombiano: primer reporte para una respuesta rápida en Salud Pública." Revista de la Universidad Industrial de Santander 51, No. 3 (2019): 208-2019, http://www.scielo.org.co/pdf/suis/ v51n3/0121-0807-suis-51-03-208.pdf

Fernández, Julián and Karen Orozco. "Migración venezolana en Colombia: retos en salud pública." Revista de la Universidad Industrial de Santander 50, No. 1 (2018): 5-6. https://revistas.uis.edu.co/index. $\mathrm{php} /$ revistasaluduis/article/view/7992

Freier, Luisa and Nicolas Parent. "The Regional Response to the Venezuelan Exodus." Current History 118 (2019): 56-61. https://www. academia.edu/39166992/The_Regional_Response_to_the_Venezuelan_Exodus

Geneva Academy. What amounts to 'a serious violation of international buman rights law'? An analysis of practice and expert opinion for the purpose of the 2013 Arms Trade Treaty, August, 2014. https://www.genevaacademy.ch/joomlatools-files/docman-files/Publications/Academy $\% 20$ Briefings/Briefing $\% 206 \% 20$ What $\% 20$ is $\% 20 \mathrm{a} \% 20$ serious $\% 20$ violation $\% 20$ of $\% 20$ human $\% 20$ rights $\% 201$ law_Academy $\% 20$ Briefing $\% 20 \mathrm{No} \% 206$.pdf

Global Health Observatory. "Maternal mortality and deaths." Accessed January 30, 2021, https://www.who.int/data/gho/data/indicators/indicator-details/GHO/maternal-mortality-ratio-(per100-000-live-births)

Gómez, Diana, Gloria Gonzalez, and Claudia Tabares. "Embarazo y migración: percepción de mujeres gestantes venezolanas sobre acceso a servicios de salud, red-salud Armenia-Colombia." Specialist diss., Fundación Universitaria del Área Andina, 2019.

Grandi, Filippo. Filippo Grandi ofrece balance de su visita a Colombia. October 8, 2018, https://www.youtube.com/watch?v=YHnlVnxaG00 
Grattan, Steven. “'Living a daily tragedy': Venezuelans struggle to survive in Colombia." The Guardian, November 1, 2019, https:// www.theguardian.com/global-development/2019/nov/01/livinga-daily-tragedy-venezuelans-struggle-to-survive-in-colombia

Gray, Bradford H. and Ewout van Ginneken. "Health Care for Undocumented Migrants: European Approaches." Commonwealth Fund pub. 1650: Issues in International Health Policy 33, (2012).

Grubessich, Alexander and Monserrat Sepúlveda. "Derecho a la salud para los inmigrantes en Chile. Normativa, estándares y problemas de acceso y atención.” Bacherlor diss., Universidad de Chile, 2020. http://repositorio.uchile.cl/bitstream/handle/2250/174822/ Derecho-a-la-salud-para-los-inmigrantes-en-Chile-normativaestandares-y-problemas-de-acceso.pdf? sequence $=1 \&$ is Allowed $=\mathrm{y}$

Henao, Luisa, Maricela Vargas, Yessica Usme, and Sergio Gómez. "Calidad de vida percibida de las madres gestantes venezolanas, en la ciudad de Medellín, durante el periodo de 2018-2019”. Revista Cies 11, (2020): 50-66. http://www.escolme.edu.co/revista/index.php/ cies/article/view/280

Hodal, Kate. "UN urged to declare full-sclae crisis in Venezuela as health system 'collapses'." The Guardian, April 5, 2019, https://www. theguardian.com/global-development/2019/apr/05/un-urged-todeclare-full-scale-crisis-in-venezuela-as-health-system-collapses

Human Rights Watch [HRW]. Venezuela: numbers highlight health crisis. November 15, 2018. https://www.hrw.org/news/2018/11/15/ venezuela-numbers-highlight-health-crisis

HRW and Johns Hopkins Bloomberg School of Public Health [JHSPH]. "Venezuela's Humanitarian Emergency." (2019). https://www. hrw.org/sites/default/files/report_pdf/venezuela0419_web.pdf

IGME-UN Inter-agency Group for Child Mortality Estimation. Most recent stillbirth, child and adolescent mortality estimates. Accessed January 30, 2021. https://childmortality.org/

Inter-American Commission of Human Rights [IACHR]. Andrea Mortlock v. the United States, Case 12.534, Report No. 63/08, July 25, 2008.

IACHR. Annual Report of 1981-1982. OEA/Ser.L/v/LL.57 Doc. 6 rev.1, September 20, 1982. Accessed May 2, 2020, https://www.acnur.org/ fileadmin/Documentos/BDL/2001/4395.pdf

IACHR. Human Mobility: Inter-American Standards. OEA/Ser.L/v/LL., Doc. 46/15, December 31, 2015. http://www.oas.org/en/iachr/reports/ pdfs/HumanMobility.pdf 
IACHr. Maternidad Concepción Palacios Hospital regarding Venezuela. Precautionary Measure No. 150-19, Res. 13/2019 (March 18, 2019), https://www.oas.org/es/cidh/decisiones/pdf/2019/13-19MC15019-VE.pdf

IACHR. National Association of ExEmployees of the Perwvian Social Security Institute et al. v. Perú, Case 12.670, Report No. 38/09, March 27, 2009.

Inter-American Court of Human Rights [IACtHR]. Acevedo Buendía and others v. Peru. Preliminary Exceptions, Merits, Reparations, and Costs, Judgement, (Ser. C) No. 210, July 1, 2009.

IACtHr. Artavia Murillo and others ("In Vitro Fertilization") v. Costa Rica. Preliminary Exceptions, Merits, Reparations, and Costs, Judgment, (Ser. C) No. 257, November 28, 2012.

IACtHR. Case of the "Five Pensioners" v. Peru. Merits, Reparations, and Costs, Judgement, (Ser. C) No. 98, February 28, 2003

IACthr. Cuscul Pivaral and others v. Guatemala. Preliminary Exceptions, Merits, Reparations, and Costs, Judgement, (Ser. C) No. 359, August 23, 2018.

IACtHr. González and others ("Cotton Field") v. México. Preliminary Exceptions, Merits, Reparations, and Costs, Judgement, (Ser. C) No. 205 November 16, 2009.

IACtHr. Hernández. v. Argentina. Preliminary Exceptions, Merits, Reparations, and Costs, Judgment, (Ser. C) No. 395, November 22, 2019.

IACtHR. I.V. v. Bolivia. Preliminary Exception, Merits, Reparations, and Costs, Judgment, (Ser. C) No. 329, November 30, 2016.

IACtHR. Poblete Vilches and others v. Chile. Merits, Reparations, and Costs, Judgment, (Ser. C) No. 349, March 8, 2018.

IACtHR. Rights and Guarantees of Children in the Context of Migration and/or in need of International Protection. Advisory Opinion, OC-21/14, (Ser. A) No. 21, August 19, 2014.

IACtHR. Rio Negro Massacres v. Guatemala. Merits, Reparations, and Costs, Judgment, (Ser. C) No. 250, September 4, 2012.

International Conference on Central American Refugees. Principles and criteria for protection and assistance of Central American refugees, repatriates, and displaced people in Latin America. May 29-31, 1989, https:// www.refworld.org/docid/4370ca8b4.html

International Committee of the Red Cross. Commentary of 1987 on the Protocol Additional to the Geneva Conventions of 12 August 1949, and relating to the Protection of Victims of Non-International Armed Conflicts (Protocol II), 8 June 1977. Commentary of 1987. 
Koechlin, José and Joaquín Eguren. "El éxodo venezolano: entre el exilio y la emigración”, OBIMID 43, (2018). http://repositorio.uarm. edu.pe/bitstream/UNIARM/2031/1/El\%20\%C3\%A9xodo\%20 venezolano $\% 20 \% 20$ entre $\% 20$ el $\% 20$ exilio $\% 20 \mathrm{y} \% 201 \mathrm{a} \% 20$ emigraci $\%$ C3\%B3n.pdf\#page $=21$.

Marín, Nicolás. “¿Qué pasa en Colombia con las venezolanas embarazadas?”. El Espectador, July 21, 2018, https://www.elespectador.com/ noticias/el-mundo/que-pasa-en-colombia-con-las-venezolanasembarazadas-articulo-801453

Martinez, Marta. 'Inside the Colombian 'War Hospital' Treating Venezuela's Pregnancy Crisis.” The New Humanitarian, November 27, 2019, https://www.thenewhumanitarian.org/news-feature/2019/11/27/ Venezuela-Colombia-pregnant-women-birth-reproductive-rightsmigration-Cucuta-maternal-care-migrants-refugees

Migración Colombia. Historical statistics. August 1, 2019, https://www. migracioncolombia.gov.co/infografias/231-infografias-2019/totalde-venezolanos-en-colombia-corte-a-30-junio-de-2019

Moloney, Anastasia. "Desperate Venezuelan migrants face homelessness as Colombia's camp closes." Reuters, October 24, 2018. https:// www.reuters.com/article/us-colombia-venezuela-migrants-feature/desperate-venezuelan-migrants-face-homelessness-as-colombias-camp-closes-idUSKCN1MY2GF

Notimérica. "Cientos de mujeres y adolescentes venezolanas embarazadas cruzan a Colombia en busca de atención médica." Notimérica, July 10, 2019. https://www.notimerica.com/sociedad/noticia-cientosmujeres-adolescentes-venezolanas-embarazadas-cruzan-colombiabusca-atencion-medica-20190710192053.html

Page, Kathleen R., Shannon Doocy, Feliciano Reyna, Julio Castro, Paul Spiegel, and Chris Beyrer. "Venezuela's Public Health Crisis: A Regional Emergency.” The Lancet 393, No. 10177 (2019): 1254-60. https://www.thelancet.com/journals/lancet/article/PIIS01406736(19)30344-7/fulltext

Pan American Health Organization [PAHO]. Once paises de América Latina y El Caribe registraron avances en la reducción de la mortalidad materna, según nuevo informe de la ONU. May 6, 2014. https://www.paho.org/ clap/index.php?option $=$ com_content\&view $=$ article\&id $=220$ :re duccion-mortalidad-materna-en-11-paises-de-la-region\&Itemid $=215 \&$ showall=1\&lang $=$ es 
PAHO. Salud en Sudamérica, edición de 2012: panorama de la situación de salud y de las politicas y sistemas de salud. 2012. https://www.paho.org/ chi/images/PDFs/salud\%20en\%20sam\%202012\%20(ene.13).pdf PAHO and World Health Organization [WHO]. Response for effective technical coordination in Venequela and neighboring countries. 162th Session of the Executive Committee. CE162/INF/22, June 18-22, 2018. https://www.paho.org/ hq/index.php?option $=$ com_docman\&view $=$ download \&category_ slug=162-en-9841\&alias $=45491$-ce162-inf-22-e-paho-tc-respond491\&Itemid=270\&lang=en

Parra, Oscar. "La protección del derecho a la salud a través de casos contenciosos ante el sistema interamericano de derechos humanos." Accessed April 30, 2020. https://www.corteidh.or.cr/tablas/ r32459.pdf

Romo, Alejandra. Pregnant women fleeing the lack of health care in Venequela. July 23, 2019, https://www.acnur.org/noticias/ historia/2019/7/5d374bcb4/mujeres-embarazadas-huyen-de-lafalta-de-atencion-medica-en-venezuela.html

Rotunno, Marco. Venezuelans Living in the Streets Find Safety at New Reception Center in Colombia. April 15, 2019, https://www.unhcr.org/news/ stories/2019/4/5cb48f934/venezuelans-living-streets-find-safetynew-reception-centre-colombia.html

Save the Children. Hundreds of heavily pregnant Venezuelan women seek treatment at Save the Children colombian border clinic. July 10, 2019. https:// www.savethechildren.net/news/hundreds-heavily-pregnant-venezuelan-women-seek-treatment-save-children-colombian-borderclinic

Schreiber, Melody. Research are surprised by the magnitude of Venezuela's health crisis. April 5, 2019. Accessed May 31, 2020. https://www.npr.org/ sections/goatsandsoda/2019/04/05/709969632/researchers-aresurprised-by-the-magnitude-of-venezuelas-health-crisis

Smith, Mitchell. "Health care for refugees." Asia Pacific Family Medicine 2 (2003): 71-73. https://citeseerx.ist.psu.edu/viewdoc/download ?doi=10.1.1.471.9091\&rep=rep1\&type $=$ pdf

United Nations Population Fund. Five reasons migration is a feminist issue. April 9, 2018, https://www.unfpa.org/news/five-reasons-migration-feminist-issue

United Nations Department of Economic and Social Affairs. World population prospects 2019. Accessed April 27, 2020. https://population.un.org/wpp/Publications/Files/WPP2019_DataBooklet.pdf 
United Nations Office of the High Commissioner for Human Rights (OHCHR). Human rights violations in the Bolivarian Republic of Venezuela: a downward spiral with no end in sight. June 2018. https://www.ohchr. org/Documents/Countries/VE/VenezuelaReport2018_EN.pdf United Nations Hight Commissioner for Refugees [UNHCR]. Department of International Protection Experts Meetings. February 19, 2014. https:// www.unhcr.org/protection/expert/3e5f78bc4/expert-meetings. html

UNHCR. "Summary conclusions on the Interpretation of the extended refugee definition contained in the 1984 Cartagena Declaration on Refugees." Expert roundtable, Montevideo (Uruguay), October 15-16, 2013. https://www.unhcr.org/53bd4d0c9.pdf

Van Praag, Oriana. Understanding the Venezuelan refugee crisis. September 13, 2019. https://www.wilsoncenter.org/article/understandingthe-venezuelan-refugee-crisis

Venezuelan, Ministerio del Poder Popular para la Salud. "Summery of the national epidemiologic situation."Boletín Epidemiologico 61, No. 52, (2012). https://www.ovsalud.org/descargas/publicaciones/ documentos-oficiales/Boletin-Epidemiologico-2012.pdf

Vera, Leonardo. “¿Cómo explicar la catástrofe económica venezolana?” Revista Nueva Sociedad 274, (2018): 83-96.

Walden, Jeffrey, Olga Valdman, Ranit Mishori, and Martha Carlough. "Building Capacity to care for refugees." Family Practice Management 24, No. 4 (2017): 21-7. https://www.aafp.org/fpm/2017/0700/ p21.html

World Bank Open Data. Indicator of pregnant women receiving prenatal care (\%) - Venezuela. Accessed March 9, 2020. https://data.worldbank. org/indicator/SH.STA.ANVC.ZS?end=2013\&locations=VE\&st art $=2000$ \& view $=$ chart

wHO. Maternal mortality: Levels and trends 2000 to 2017. Estimates by who, unicef, unfpa, World Bank Group and the United Nations Population Division. 2019. https://www.who.int/reproductivehealth/publications/ maternal-mortality-2000-2017/en/ 
